\title{
Construction of uricase-overproducing strains of Hansenula polymorpha and its application as biological recognition element in microbial urate biosensor
}

\author{
Kostyantyn V Dmytruk ${ }^{1 *}$, Oleh V Smutok ${ }^{1}$, Olena V Dmytruk ${ }^{1}$, Wolfgang Schuhmann ${ }^{2}$ and Andriy A Sibirny ${ }^{1,3}$
}

\begin{abstract}
Background: The detection and quantification of uric acid in human physiological fluids is of great importance in the diagnosis and therapy of patients suffering from a range of disorders associated with altered purine metabolism, most notably gout and hyperuricaemia. The fabrication of cheap and reliable urate-selective amperometric biosensors is a challenging task.

Results: A urate-selective microbial biosensor was developed using cells of the recombinant thermotolerant methylotrophic yeast Hansenula polymorpha as biorecognition element. The construction of uricase (UOX) producing yeast by over-expression of the uricase gene of H. polymorpha is described. Following a preliminary screening of the transformants with increased UOX activity in permeabilized yeast cells the optimal cultivation conditions for maximal UOX yield namely a 40-fold increase in UOX activity were determined.

The UOX producing cells were coupled to horseradish peroxidase and immobilized on graphite electrodes by physical entrapment behind a dialysis membrane. A high urate selectivity with a detection limit of about $8 \mu \mathrm{M}$ was found.
\end{abstract}

Conclusion: A strain of H. polymorpha overproducing UOX was constructed. A cheap urate selective microbial biosensor was developed.

Keywords: urate, oxidoreductase, methylotrophic yeast, amperometric biosensor, cell-based biosensor

\section{Background}

Urate is the final purine intermediate of the purine nucleotide catabolism in human [1]. Normally, urate is not accumulated in human body fluids and hence its concentration is a valuable indicator in clinical diagnosis [2] indicating gout, hyperuricemia, or Lesch-Nyhan syndrome [3]. Elevated urate levels are also related to e.g. increased alcohol and cholesterol consumption, obesity, diabetes, kidney and heart diseases, and they are considered to be a risk factor for cardiovascular diseases [4].

Uricase (urate oxidase, UOX, EC 1.7.3.3) is a key enzyme in the purine degradation pathway. It catalyzes

\footnotetext{
* Correspondence: dmytruk@cellbiol.Iviv.ua

'Institute of Cell Biology, NAS of Ukraine, Drahomanov Street 14/16, Lviv 79005, Ukraine

Full list of author information is available at the end of the article
}

the oxidation of urate in the presence of oxygen, producing allantoin and $\mathrm{CO}_{2}$. Uricase does not require an additional cofactor other than oxygen for the enzymatic reaction and is therefore widely used for the amperometric determination of urate to diagnose gout and the above mentioned diseases and conditions. For urate determination in serum and urine, several biosensors have been reported [5-8]. Numerous amperometric urate biosensors based on uricase or uricase coupled with peroxidase varying in the type of electrode, immobilization technique, ability and type of redox mediator (s), conductive polymers etc. have been described [9-15].

Several new amperometric uric acid biosensors were fabricated by immobilizing uricase onto gold nanoparticles or carbon nanotubes [16-18]. These urate-selective biosensors are using expensive commercially available

\section{C) Biomed Central}


uricases purified from Bacillus fastidiosus, Arthrobacter globiformis, or Candida utilis. Therefore, the fabrication of cheap urate-selective amperometric biosensors is still a challenging task.

In this work, we introduce a novel microbial urateselective amperometric biosensor based on the cells of the uricase-overproducing recombinant yeast $H$. polymorpha.

\section{Results and Discussion}

Construction of the uricase-overproducing recombinant yeast $\mathrm{H}$. polymorpha

Uricase-overproducing transformants of $H$. polymorpha were constructed using straight-forward microbiological techniques. The expression of target genes and corresponding enzymatic activity in yeasts is increased by repeated amplification of the required nucleotide sequence $[19,20]$. The plasmid pGLG61 contains a bacterial $A P H$ gene (aminoglucoside-3-phosphotransferase) as dominant marker whose expression is impaired, and the sequence of the HARS36 (TEL188) autonomic replicating sequence. This ensures multiple tandem integration of pGLG61 into the $H$. polymorpha telomere regions on medium containing the antibiotic G418 [21].

The recombinant plasmid pGLG61_UOX (Figure 1A) derived from pGLG61 was transformed to the recipient strain H. polymorpha C-105 (gcrl, catX), impaired in glucose repression and devoid of catalase activity. The transformants were grown on YPS medium in the presence of increasing concentrations of G418. The highest concentration of G418 which allowed the transformants to grow was $1 \mathrm{mg} \mathrm{mL}^{-1}$. The transformants were stabilized by cultivation in non-selective media for 10-12 generations with further shifting to the selective media with G418. The presence of the expression cassette in the stable transformants was examined by diagnostic PCR using the primers Ko183/Ko190 and the genomic
DNA of stable transformants as a template. Fragments of predictable size $(\sim 2.7 \mathrm{~kb})$ were obtained (data not shown).

The parental strain C-105 exhibits impairment in glucose catabolite repression of alcohol oxidase (AOX) synthesis resulting in the induction of AOX in a glucose containing growth medium [22]. Stable transformants bearing $U O X$ under control of the AOX promoter with increased UOX enzyme activity were screened by a plate patches assay in solid glucose-containing medium. Finally, six positive recombinant strains $(20,22,24,28$, 32, and 36) were selected (Figure 1B).

The UOX activity in cell-free extracts of the selected strains was determined spectrophotometrically. As shown in Figure 2A, the UOX activity of the selected strains varied between 0.4 and $2.67 \mathrm{U} \mathrm{mL}^{-1}$, while the initial strain of $H$. polymorpha $\mathrm{C}-105$ showed no significant enzyme activity under the same growth conditions. The C-105 cells were cultivated in urate containing medium for induction of uricase. The UOX activity of $\mathrm{C}-105$ cultivated under inducing conditions was $0.067 \mathrm{U}$ $\mathrm{mL}^{-1}$. Thus, the most active strain 22 showed a fortyfold higher UOX activity as compared to the parental strain.

The vector used for construction of UOX producers, pGLG61_UOX, supports multiple tandem integration into the telomeric chromosome region [21]. The uricase gene copy number of strain 22 was established by quantitative Southern dot-blot via serial dilutions of the genomic DNA and comparing to untransformed strain's single-copy signal of the $H$. polymorpha uricase gene. The estimated vector copy number in transformants which are resistant to $1 \mathrm{mg} \mathrm{mL}^{-1} \mathrm{G} 418$ was approximately 10 (Figure 3).

The dependence of UOX activity of strain 22 on the growth phase is presented in Figure 2B. The maximal level of UOX activity in cell-free extracts occurred after
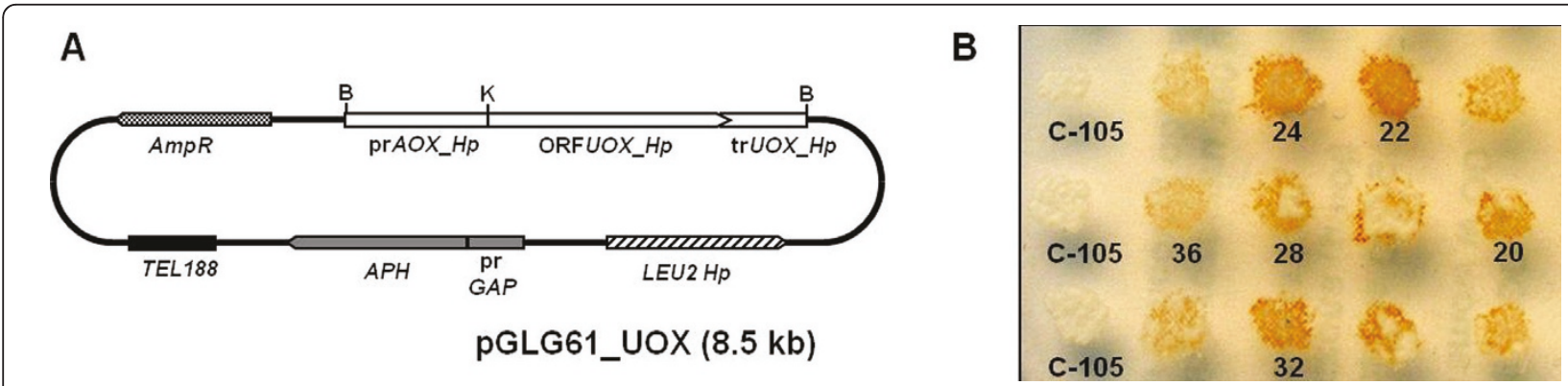

Figure 1 A: Circular scheme of the plasmid pGLG61_UOX (8.5 kb). The HpAOX promoter and UOX ORF with terminator region are shown as open boxes. The LEU2 gene H. polymorpha is shown as hatched box. Gene AmpR conferring resistance to ampicillin is shown as chequered boxes. The H. polymorpha truncated glyceraldehyde-3-phosphate dehydrogenase (GAP) promoter and the geneticin resistance gene (APH) are shown as grey boxes, and the tellomeric region (TEL 188) as black box. Restriction sites: B, BamHl; K, Kpnl. B: Visualization of UOX activity in situ in cells grown on mineral medium plates supplemented with glucose, incubated for $18 \mathrm{~h}$, and then overlain with UOX reaction mixture with permeabilizing agent as described in Materials and Methods section. 


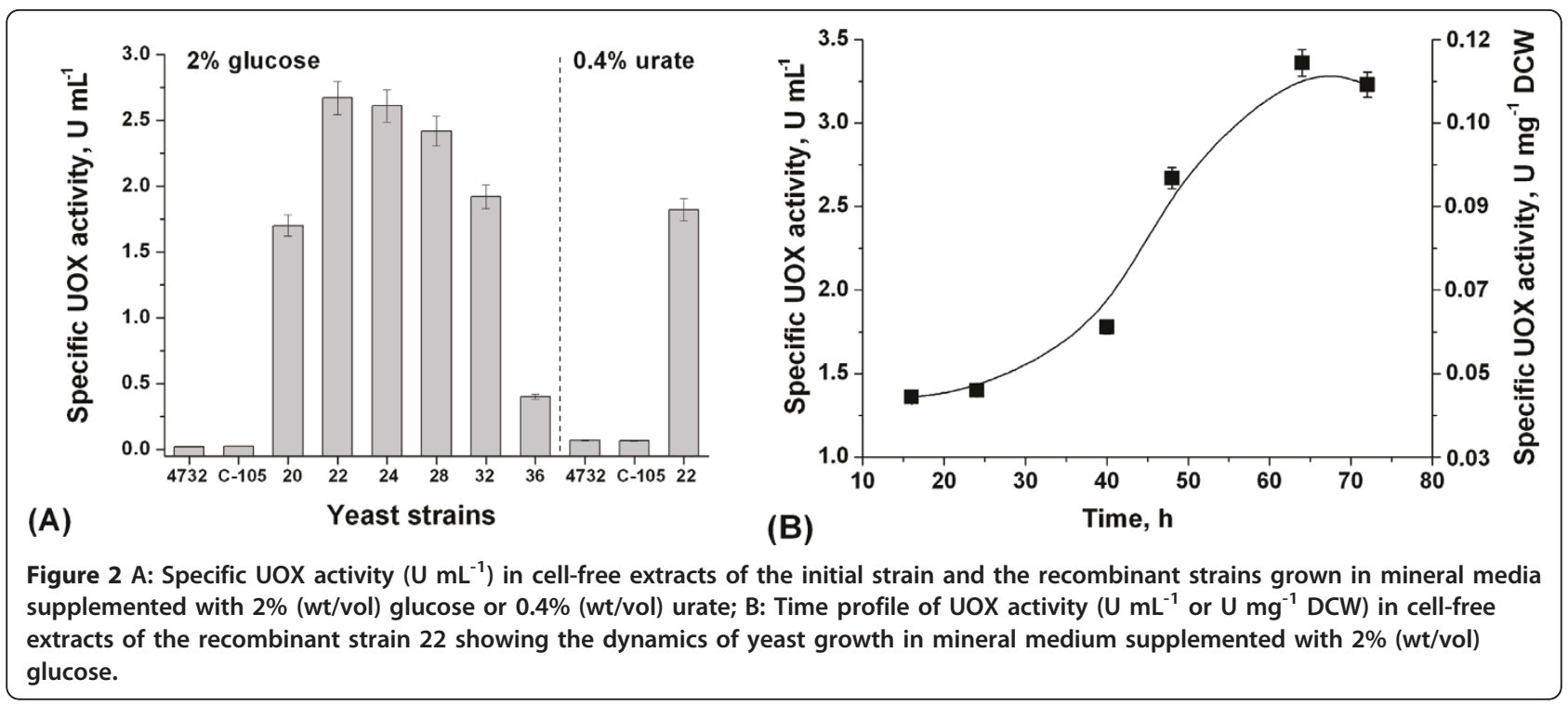

$64 \mathrm{~h}$ of cell cultivation $\left(3.36 \mathrm{U} \mathrm{mL}^{-1}\right.$ or $0.112 \mathrm{U} \mathrm{mg}^{-1}$ $\mathrm{DCW})$. This is in agreement with the dynamics of the development of the AOX activity in $\mathrm{C}-105$ strain during cultivation in the same medium. As the yeast $H$. polymorpha belongs to the class of thermotolerant species

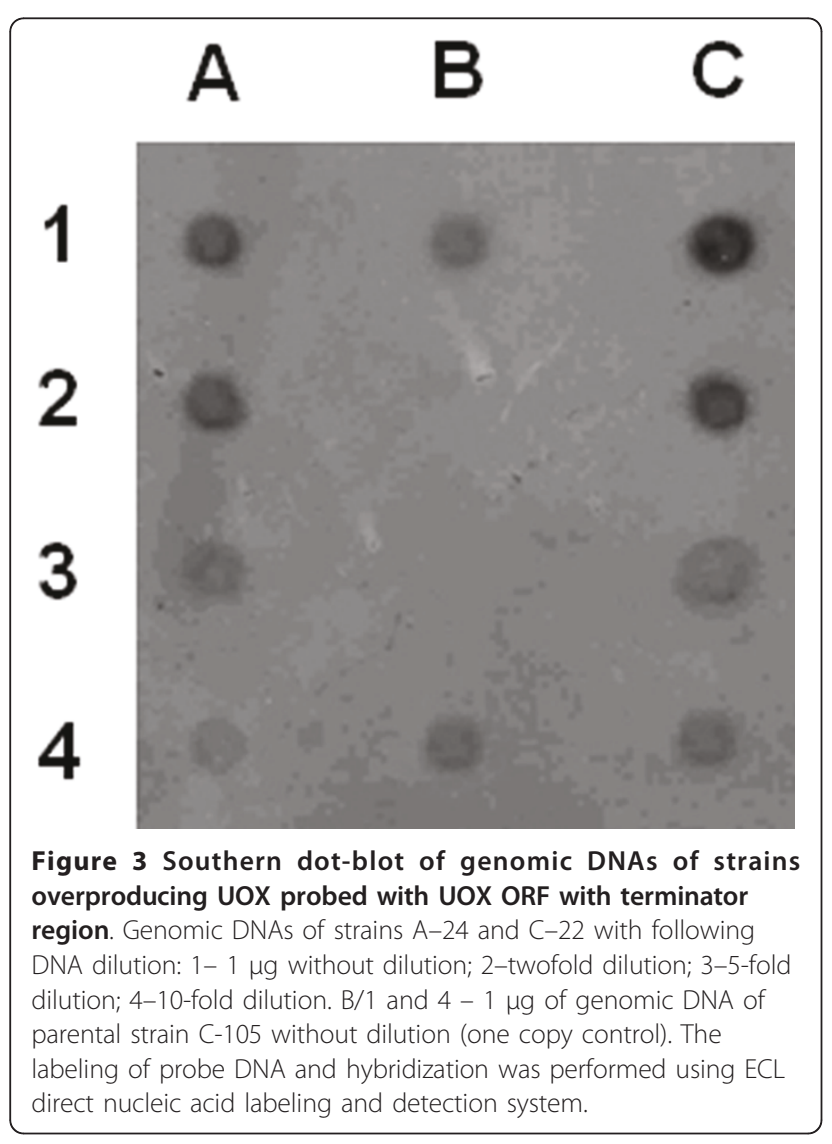

with highest growth temperature around $50^{\circ} \mathrm{C}$ [23], the thermal stability of UOX was examined by incubating a cell-free extract for $10 \mathrm{~min}$ at $50^{\circ} \mathrm{C}$. Uricase lost about $32 \%$ of its activity and reached an activity of $2.3 \mathrm{U} \mathrm{mL}^{-1}$ at $50^{\circ} \mathrm{C}$. Obtained data is in accordance with the thermal stability of uricase of C. utilis. Treatment at $50^{\circ} \mathrm{C}$ caused about $60 \%$ of activity maximum in the crude extract of the yeast [24].

The constructed overproducing strains exhibit significantly lower UOX activity as compared with commercially available recombinant UOX from Escherichia coli or Saccharomyces cerevisiae $[25,26]$. However, their genetic background makes the constructed strains a unique ideal biorecognition element in microbial urateselective amperometric biosensors. The block in catalase activity leads to the generation of $\mathrm{H}_{2} \mathrm{O}_{2}$ as a result of urate oxidation that can be easily detected amperometrically. A defect in the gene responsible for catalase synthesis forced the cells to develop a mechanism of $\mathrm{H}_{2} \mathrm{O}_{2}$ depletion through its extrusion from the cell $[22,27]$. $\mathrm{H}_{2} \mathrm{O}_{2}$ released from the cell facilitating its detection. The impairment in glucose repression of the constructed strains allows for the overproduction of UOX in a low-priced glucose-containing growth medium that does not required expensive inducers, i.e. uric acid [28].

\section{Evaluation and optimization of the urate biosensor}

UOX catalyzes in vivo oxidation of uric acid in the presence of oxygen as an oxidizing agent producing allantoin and $\mathrm{CO}_{2}$ as oxidation products of uric acid and hydrogen peroxide as a reduction product of $\mathrm{O}_{2}$. The amperometric detection of uric acid can be performed by electrochemical oxidation of the produced $\mathrm{H}_{2} \mathrm{O}_{2}$. However, there is one serious problem which has to be 
solved in such sensors, namely that uric acid itself is oxidized at $\mathrm{Pt}, \mathrm{Au}$ and carbon electrodes at the potentials necessary to oxidize $\mathrm{H}_{2} \mathrm{O}_{2}$ [29-31]. Amperometric detection of $\mathrm{H}_{2} \mathrm{O}_{2}$ using horseradish peroxidase (HRP) for its biocatalytic reduction to water has been proposed $[30,31]$.

A bienzyme system comprising UOX and one of a hydrogen peroxide decomposing enzymes (HRP, catalase (CAT) or microperoxidase (MP-11)) was evaluated for the construction of urate-selective biosensors. The reaction scheme and electron-transfer pathway is presented in Figure 4.

Biosensor based on living cells of the uricase-overproducing recombinant strain of $H$. polymorpha coupled with HRP exhibited the highest kinetic parameters $I^{\max }$ $=210 \mathrm{nA}, \mathrm{K}_{\mathrm{M}}=0.47 \mathrm{mM}$ for urate (Figure 5). Kinetic parameters of sensors based on CAT or MP-11 were quite similar $\left(\mathrm{I}^{\max }=137\right.$ or $135 \mathrm{nA}, \mathrm{K}_{\mathrm{M}}=0.38$ or 0.30 $\mathrm{mM}$, respectively; Figure 5), however, due to the fact that the HRP-based sensors showed the highest $\mathrm{K}_{\mathrm{M}^{-}}$ value all further investigations were done with HRPbased sensors. This feature provides a wider range of linearity thus improving the accuracy of the analysis by reducing of the necessary sample dilutions. Moreover the response time for the sensor based on HRP (1-1.2 min) was shorter than that for CAT (1.2-1.4 min) or MP-11 (1.5-1.8 min).

The immobilization of the strain 22 cells on graphite disk electrodes was achieved by physical fixation behind dialysis membranes. For further optimization, the ratio of HRP to the cells and hence to UOX was varied. A combination of $1 \mu \mathrm{L}$ of HRP solution and $1 \mu \mathrm{L}$ of cell suspension showed the highest current response (Figure 6). The increase in the HRP/cell ratio let to a decrease of the current response apparently due to physical blocking of the electrode surface with HRP. The response time for the optimized sensor upon addition of $0.1 \mathrm{mM}$ urate was about $5.5 \mathrm{nA} \mathrm{min}{ }^{-1}$. A typical current response of a sensor with optimized architecture is

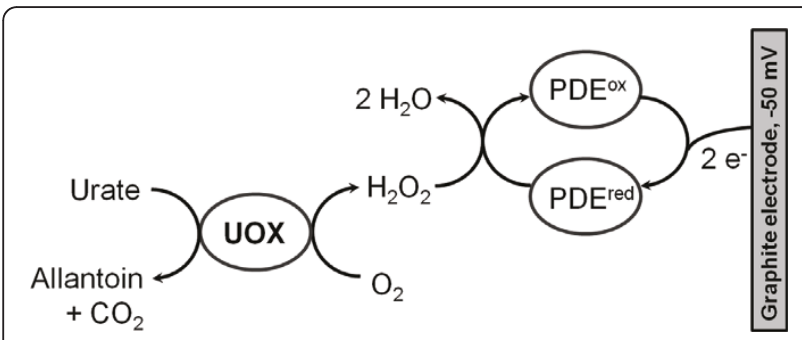

Figure 4 Reaction scheme and electron-transfer pathway of the proposed urate biosensor. PDE - hydrogen peroxide decomposing enzymes (HRP, CAT or MP-11). PDE ${ }^{\overline{0 x}}$ and PDE ${ }^{\text {red }}$ oxidized and reduced forms of hydrogen peroxide decomposing enzymes, UOX - urate oxidase.

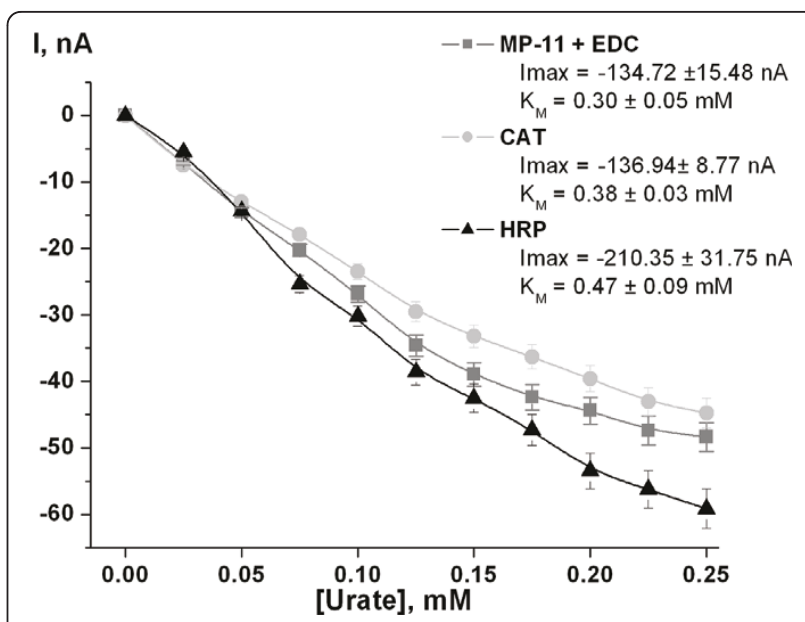

Figure 5 Screening of the hydrogen peroxide decomposing enzymes (MP-11, CAT or HRP). $3.05 \mathrm{~mm}$ graphite rod electrodes,

$-50 \mathrm{mV}$ vs. Ag/AgCl, $1 \mu \mathrm{L}$ of each enzymes and $1 \mu \mathrm{L}$ of cell suspension. PDE and suspension of recombinant cells were entrapped behind the dialysis membrane (cut off $10 \mathrm{kDa}$ ). Testing solution: $30 \mathrm{mM}$ Tris- $\mathrm{HCl}$ (pH 8.9); working volume: $20 \mathrm{~mL}$; stock solution of uric acid: $10 \mathrm{mM}$ in $30 \mathrm{mM}$ Tris- $\mathrm{HCl}(\mathrm{pH}$ 8.9).

shown in Figure 7. The detection limit of the sensor was determined to be $8 \mu \mathrm{M}$ and the apparent $K_{M}$ value obtained from several independent calibrations was 0.46 $\mathrm{mM}$ for urate. The optimal $\mathrm{pH}$ range for the urate biosensor was 8.5 to 8.9 , the optimal temperature range was between 36 to $42^{\circ} \mathrm{C}$ (data not shown).

For application of the optimized prototype of the urate sensor in real samples, its selectivity with respect to potential interferences such as ascorbate, citrate, L-

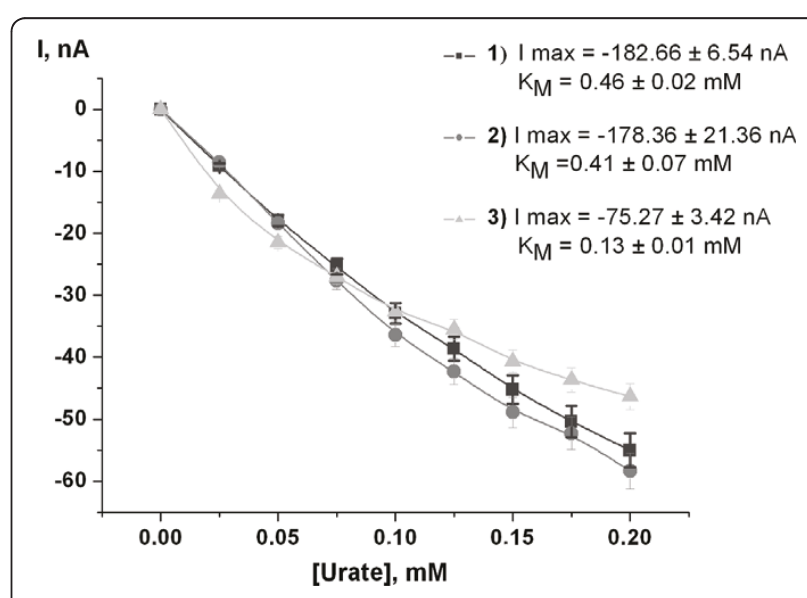

Figure 6 Evaluation of the optimal enzyme ratio $(3.05 \mathrm{~mm}$ graphite electrodes, $-50 \mathbf{m V}$ vs. Ag/AgCl). $1 \mu \mathrm{L} \mathrm{HRP/1} \mu \mathrm{L}$ of cell

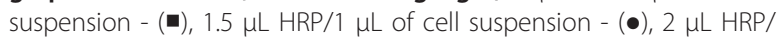
$1 \mu \mathrm{L}$ of cell suspension - $(\mathbf{\Delta})$. HRP and cell suspension were entrapped behind the dialysis membrane (cut off $10 \mathrm{kDa}$ ). Testing solution: $30 \mathrm{mM}$ Tris- $\mathrm{HCl}(\mathrm{pH}$ 8.9); working volume: $20 \mathrm{~mL}$; stock solution of uric acid: $10 \mathrm{mM}$ in $30 \mathrm{mM}$ Tris- $\mathrm{HCl}(\mathrm{pH}$ 8.9). 

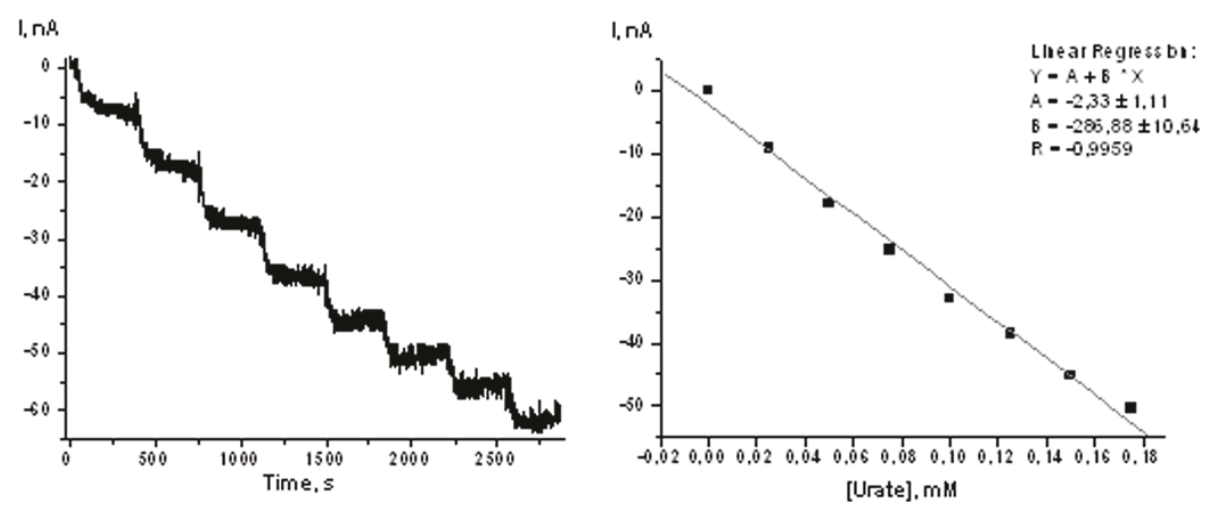

Figure 7 Left: Chronoamperometric current response upon subsequent additions of urate aliquots obtained with a microbial biosensor entrapment behind a dialysis membrane; Right: urate calibration curve $(-50 \mathbf{m V}$ vs. Ag/ $\mathbf{A g C l})$. Testing solution: $30 \mathrm{mM} \mathrm{Tris-HCl}$ (pH 8.9); working volume: $20 \mathrm{~mL}$; stock solution of uric acid: $10 \mathrm{mM}$ in $30 \mathrm{mM}$ Tris- $\mathrm{HCl}(\mathrm{pH}$ 8.9).

lactate, succinate, D-glucose, and ethanol is of great importance. Hence, the current response of the urate biosensor was evaluated with respect to these substances (Figure 8 ). The biosensor exhibits about $10 \%$ of crosssensitivity to ethanol and ascorbate relative to the urate output level. However, no relative cross sensitivity to the other investigated compounds was observed. As the interfering compounds are present in significantly lower concentrations e.g. in urine, the impact of these compounds on the determination of urate in most real samples is assumed to be negligible.

The main characteristics of the developed urate selective microbial biosensors are comparable with

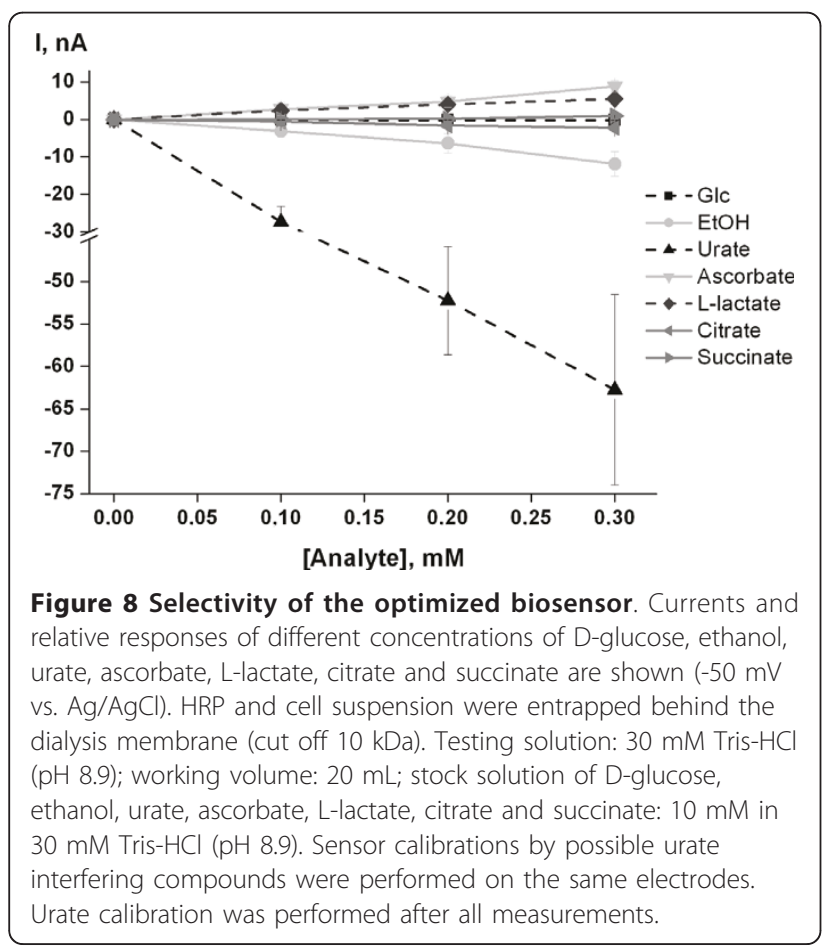

previously reported results, such as an UOX-microperoxidase bi-enzyme system based on Au-electrode [13] or a redox mediator $(\mathrm{FcCOOH})$ containing UOX-HRP system based on graphite electrode [12]. The detection limit is higher $(8 \mu \mathrm{M}$ compared to $2 \mu \mathrm{M}$ or $0.6 \mu \mathrm{M}$ of urate), while the linear detection range is wider (180 $\mu \mathrm{M}$ versus $75 \mu \mathrm{M}$ or $120 \mu \mathrm{M}$ of urate). The $\mathrm{K}_{\mathrm{M}^{\text {-values }}}$ [13] coincide with our results. At the same time the estimated costs of the biosensor based on the urate selective microbial cells appears to be significantly reduced.

\section{Conclusions}

A strain of $H$. polymorpha overproducing UOX was constructed. Genomic integration of expression cassettes of the uricase gene under the control of the strong $H$. polymorpha AOX promoter resulted in a 40-fold increase in the UOX activity compared to the parental strain. A method for preliminary screening of the recombinant strains was developed. The conditions for strain cultivation were optimized to ensure the maximal amount of the target enzyme.

The strain identified as the one possessing highest UOX activity was used for the construction of amperometric urate biosensors. A urate-selective biorecognition layer was designed comprising living cells of the recombinant $H$. polymorpha strain coupled to HRP. The terminal amperometric detection was achieved by direct electron transfer between HRP and the graphite electrode at $-50 \mathrm{mV}$ vs. $\mathrm{Ag} / \mathrm{AgCl}$. The sensor design was optimized and a ratio of $\mathrm{HRP} /$ cells of $1: 1$ yielded the highest current response. The detection limit of the optimized sensor design was $8 \mu \mathrm{M}$ and the apparent $\mathrm{K}_{\mathrm{M}}$-value $0.46 \mathrm{mM}$. Future research will be directed to further increasing the UOX activity of $H$. polymorpha and optimization of the electron-transfer cascade of the described bi-enzyme system. 


\section{Materials and methods Materials}

Urate, L-lactic acid, horseradish peroxidase (HRP, EC 1.11.1.7), microperoxidase-11 (MP-11), 1-ethyl-3-(3dimethylaminopropyl)carbodiimide (EDC), catalase (CAT, EC 1.11.1.6) and uricase (UOX, EC 1.7.3.3) were obtained from Sigma. Succinic acid was from Fluka. Citric acid monohydrate, ascorbic acid, $\mathrm{D}(+)$-glucose monohydrate were from J.T. Baker. Ethanol (abs.) was from Riedel-de Haën and EDTA was from Serva; $\left(\mathrm{NH}_{4}\right)$ ${ }_{2} \mathrm{SO}_{4}, \mathrm{Na}_{2} \mathrm{HPO}_{4}, \mathrm{KH}_{2} \mathrm{PO}_{4}, \mathrm{MgSO}_{4}, \mathrm{CaCl}_{2}$ were obtained from Merck. Dialysis membranes (cut off $10 \mathrm{kDa}$ ) were from Biomol. All chemicals were of analytical grade and all solutions were prepared using HPLC-grade water. Solutions of glucose, ethanol, urate, L-lactic acid, ascorbic acid, succinic acid and citric acid were prepared in 30 mM Tris- $\mathrm{HCl}$ buffer, $\mathrm{pH}$ 8.9.

\section{Strains, media, cultivation and preparation of microbial cells}

Cultivation of $H$. polymorpha CBS 4732 (leu2-2) [32], $\mathrm{C}-105$ (gcr1 cat X) [22] and the recombinant producer of uricase was performed in flasks on a shaker $(200$ $\mathrm{rpm})$ at $37^{\circ} \mathrm{C}$ in a medium containing $\left(\mathrm{g} \mathrm{L}^{-1}\right):\left(\mathrm{NH}_{4}\right)$ ${ }_{2} \mathrm{SO}_{4}-3.5 ; \mathrm{KH}_{2} \mathrm{PO}_{4}-1.0 ; \mathrm{MgSO}_{4} \times 7 \mathrm{H}_{2} \mathrm{O}-0.5 ; \mathrm{CaCl}_{2}$ - 0.1 ; yeast extract - 6 . Glucose $\left(20 \mathrm{~g} \mathrm{~L}^{-1}\right)$ was used as carbon source. For induction of uricase, the cells from the mid-exponential growth phase were washed once in the mineral medium and transferred to shake-flask cultures supplemented with $4 \mathrm{~g} \mathrm{~L}^{-1}$ urate as carbon source. Cultivation of the recombinant strain 22 was performed for $64 \mathrm{~h}$. To prevent degradation of target enzyme, after washing, the cells were suspended in $30 \mathrm{mM}$ Tris- $\mathrm{HCl}$ buffer $(\mathrm{pH} 8.9)$ containing $1 \mathrm{mM}$ phenylmethylsulfonyl fluoride (PMSF) and $1 \mathrm{mM}$ ethylenediaminetetraacetic acid (EDTA) followed by lyophilization. Before experiments, the lyophilized yeast cells were re-suspended to $30 \mathrm{mg} \mathrm{mL}^{-1}$ dry cell weight (DCW) in $30 \mathrm{mM}$ Tris- $\mathrm{HCl}$ buffer, $\mathrm{pH} 8.9$, containing $1 \mathrm{mM}$ EDTA. Cell-free extracts were obtained by vortexing with glass beads (425-600 $\mu \mathrm{m}$; Sigma Cat No. G-8772) followed by centrifugation as described previously [33].

The yeast C-105 (gcr1 cat X) was grown on YPS (10 g $\mathrm{L}^{-1}$ yeast extract, $20 \mathrm{~g} \mathrm{~L}^{-1}$ peptone, and $20 \mathrm{~g} \mathrm{~L}^{-1}$ sucrose) at $37^{\circ} \mathrm{C}$ and used as a recipient strain for transformation experiments. For the selection of yeast transformants on YPS, $0.5-1.5 \mathrm{mg} \mathrm{mL}^{-1}$ of the antibiotic geneticin (G418) was added. The E. coli strain DH5 $\alpha$ (Ф80dlacZ $\Delta \mathrm{M} 15$, recA1, endA1, gyrA96, thi-1, hsdR17 $\left(\mathrm{r}_{\mathrm{K}}{ }^{-}, \mathrm{m}_{\mathrm{K}}{ }^{+}\right)$, supE44, relA1, deoR, $\triangle($ lacZYA-argF)U169) was used as a host for propagation of plasmids. The strain DH5 $\alpha$ was grown at $37^{\circ} \mathrm{C}$ in $\mathrm{LB}$ medium as described previously
[33]. Transformed E. coli cells were maintained on a medium containing $100 \mathrm{mg} \mathrm{L}^{-1}$ ampicillin.

\section{Plasmid construction and molecular techniques}

The $H$. polymorpha uricase gene with a terminator region (orf 201 hp_contig08, in the H. polymorpha genome database, Rhein Biotech) and the alcohol oxidase gene promoter were amplified from the genomic DNA of $H$. polymorpha strain CBS 4732 using the corresponding pairs of primers: Ko189 5'-CAA TCT AAA GTA CAA AAA CAA AGG TAC CAT GGC TGT

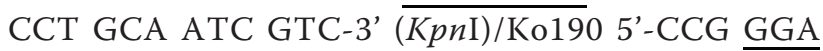
TCC TAC TCT TTG ATT GCC TCC-3' (BamHI) and Ko183 CGC GGA TCC TCG TTT AGA ACG TCC TG-3' (BamHI)/Ko188 5'-GAC GAT TGC AGG ACA GCC ATG GTA CCT TTG TTT TTG TAC TTT AGA TTG-3' (KpnI). The primers Ko183 and Ko190 were used to obtain a $\sim 2.7 \mathrm{~kb}$ fragment containing the $H$. polymorpha uricase gene with a terminator region driven by the alcohol oxidase gene promoter by overlap PCR. This fragment was treated with restriction endonuclease BamHI and cloned into the BamHI-linearized and dephosphorylated plasmid pGLG61 [21], resulting in the recombinant constructs pGLG61_UOX (Figure $1 \mathrm{~A})$.

Standard cloning techniques were applied [33]. PCRamplification of the fragments of interest was done with Platinum ${ }^{\circledR}$ Taq DNA Polymerase High Fidelity (Invitrogen) according to the manufacturer specification. PCR was performed in a GeneAmp ${ }^{\circledR}$ PCR System 9700 thermocycler (Applied Biosystems). Transformation of the yeast $H$. polymorpha by electroporation was carried out as described previously [34]. Preparation of the total DNA from yeast was carried out by using the DNeasy ${ }^{\circledR}$ Tissue Kit (Qiagen). Plasmid DNA isolations from $E$. coli were performed by using NucleoSpin ${ }^{\circledR}$ Plasmid (Macherey-Nagel).

For quantitative Southern dot-blot, preparations of serial dilutions of yeast genomic DNAs were denatured in $0.4 \mathrm{M} \mathrm{NaOH}$, spotted $2 \mu \mathrm{L}$ per dot onto dry nylon membrane (Hybond $\mathrm{N}_{+}$, Amersham Pharmacia Biotech). The labeling of probe DNA and hybridization was performed using non-radioactive ECL direct nucleic acid labeling and detection system (Amersham Pharmacia Biotech) according to the manufacturer's manual.

\section{Urate oxidase assay}

The UOX activity in cell-free extracts was determined spectrophotometrically by following the decrease of the absorbance at $293 \mathrm{~nm}$. Assay mixtures contained 0.1 $\mathrm{mM}$ urate in $0.1 \mathrm{M}$ Tris-HC1 buffer ( $\mathrm{pH}$ 8.9) [35]. The reaction was started by the addition of the cell extract. Enzyme assays were performed at $25^{\circ} \mathrm{C}$. One unit was 
defined as the amount of enzyme necessary to transform $1 \mu \mathrm{mol}$ of urate into allantoin in $1 \mathrm{~min}$ at $25^{\circ} \mathrm{C}$ and $\mathrm{pH}$ 8.9.

Strains with elevated UOX activity were screened by a plate patch assay. UOX activity was visualized by the rate of $\mathrm{H}_{2} \mathrm{O}_{2}$ formation. $\mathrm{H}_{2} \mathrm{O}_{2}$ is formed in the reaction of UOX with urate and can be monitored by the peroxidative oxidation of $o$-dianisidine in the presence of horseradish peroxidase (HRP) leading to a purple colouring of the patches. The transformants were patched onto mineral medium agar plates supplemented with glucose. After $18 \mathrm{~h}$ of incubation at $37^{\circ} \mathrm{C}$, the plates were overlaid with $9 \mathrm{~mL}$ of the UOX activity assay mixture containing $0.1 \mathrm{M}$ Tris- $\mathrm{HC} 1$ buffer $(\mathrm{pH} 8.9), 0.7 \%$ (wt/vol) agar, digitonin $\left(1 \mathrm{mg} \mathrm{mL}^{-1}\right), o$-dianisidine $(0.5$ $\left.\mathrm{mg} \mathrm{mL}{ }^{-1}\right)$, HRP Sigma RZ $1.1\left(0.13 \mathrm{mg} \mathrm{mL}^{-1}\right)$, and urate $(0.1 \mathrm{mM})$. The plates were incubated at $37^{\circ} \mathrm{C}$ for up to 1 h. Patches that stained faster were selected for further experiments. All assay experiments were repeated at least twice.

\section{Preparation and evaluation of the cell-based biosensors}

Amperometric cell-based biosensors were evaluated using constant-potential amperometry in a three-electrode configuration with an $\mathrm{Ag} / \mathrm{AgCl} / \mathrm{KCl}(3 \mathrm{M})$ reference electrode and a Pt-wire counter electrode. Amperometric measurements were carried out using a bipotentiostat (EP 30, Biometra, Göttingen, Germany) connected to a personal computer via a RS232 port for data acquisition. Graphite rods (type RW001, $3.05 \mathrm{~mm}$ diameter, Ringsdorff Werke, Bonn, Germany) were used as working electrodes. They were sealed in glass tubes by means of epoxy glue exposing a graphite disk. The electrodes were polished on emery paper and ultrasonicated in water.

HRP solution (300 $\left.\mathrm{U} \mathrm{mL}^{-1}\right)$ was dropped on the electrode surface and dried at $4^{\circ} \mathrm{C}$ for $15 \mathrm{~min}$. Alternative CAT solution (400 $\left.\mathrm{U} \mathrm{mL}^{-1}\right)$ or MP-11 $(0.05 \mathrm{mM})$ containing EDC ( $2.5 \mathrm{mM})$ were used. Amount of hydrogen peroxide decomposing enzymes was $1 \mu \mathrm{L}$, unless otherwise stated. Then, $1 \mu \mathrm{L}$ of the freshly prepared cells were dropped on top of the hydrogen peroxide decomposing enzymatic layer (HRP, CAT or MP-11) and dried at $4^{\circ} \mathrm{C}$ for $15 \mathrm{~min}$. Physical fixation was performed with a piece of dialysis membrane and an O-ring. Before use, the electrodes were rinsed with $30 \mathrm{mM}$ Tris- $\mathrm{HCl}$ buffer, $\mathrm{pH} 8.9$. Defined amount of analyte was injected to measuring cell after sensor stabilization (current baseline). The time of the sensor-system stabilization was 9-10 min. The additional of the next urate concentration was performed for the identical time periods (for approximately $5 \mathrm{~min}$ ). The electrodes were washed with distilled water between measurements. Measurements were repeated at least three times to ensure reproducibility. Between experiments, the cell-modified electrodes were stored in buffer at $4^{\circ} \mathrm{C}$.

\section{Acknowledgements}

We are grateful to S. Neugebauer and A. Okunola (Ruhr-Universität Bochum) for revising the manuscript. We thank Rhein Biotech $\mathrm{GmbH}$ (Düsseldorf, Germany) for providing access to the H. polymorpha genome database. This work was supported by individual research fellowships from FEMS 2008-2.

\section{Author details}

${ }^{1}$ Institute of Cell Biology, NAS of Ukraine, Drahomanov Street 14/16, Lviv 79005, Ukraine. ${ }^{2}$ Analytische Chemie - Elektroanalytik \& Sensorik, RuhrUniversitat Bochum, Universitätsstr. 150, D-44780 Bochum, Germany. ${ }^{3}$ Department of Biotechnology and Microbiology, Rzeszow University, Cwiklinskiej 2, 35-601 Rzeszow, Poland.

\section{Authors' contributions}

KVD carried out the molecular genetic studies, drafted and edited the manuscript. OVS and KVD constructed and characterized the amperometric biosensor. OVD performed the biochemical studies. OVS, WS and AAS codrafted the manuscript. WS and AAS supervised some of the work and participated in the design of the experiments. All authors read and approved the final version of the manuscript.

Received: 21 February 2011 Accepted: 25 May 2011

Published: 25 May 2011

\section{References}

1. Watts RWE: Molecular variation in relation to purine metabolism. J Clin Pathol Suppl 1974, 8:48-63.

2. Bhargava A, Lai H, Pundir C: Discrete analysis of serum uric acid with immobilized uricase and peroxidase. J Biochem Biophys Meth 1999, 39:125-136.

3. Ze J, Hsu C: A selective voltammetric method for uric acid detection at Nafion-coated carbon paste electrodes. Talanta 1997, 46:1363-1369.

4. Inoue K, Namiki T, Iwasaki Y, Yoshimura Y, Nakazawa H: Determination of uric acid in human saliva by high-performance liquid chromatography with amperometric electrochemical detection. J Chromatogr 2003, 785:57-63.

5. Keedy F, Vadgama P: Determination of urate in undiluted whole blood by enzyme electrode. Biosens Bioelectron 1991, 6:491-499.

6. Gilmartin M, Hart J: Prototype, solid-phase, glucose biosensor. The Analyst 1994, 119:833-840.

7. Motonaka J, Miyata K, Faulkner L: Micro enzyme-sensor with osmium complex and a porous carbon for measuring uric acid. Anal Lett 1994, 27:1-13.

8. Zhang Y, Shen W, Gu R, Zhu J, Xue R: Amperometric biosensor for uric acid based on uricase-immobilized silk fibroin membrane. Anal Chim Acta 1998, 369:123-128.

9. Hoshi T, Saiki H, Anzai J: Amperometric uric acid sensors based on polyelectrolyte multilayer films. Talanta 2003, 61:363-368.

10. Zhang F, Wang X, Ai S, Sun Z, Wan Q, Zhu Z, Xian Y, Jin L, Yamamoto K: Immobilization of uricase on $\mathrm{ZnO}$ nanorods for a reagentless uric acid biosensor. Anal Chim Acta 2004, 519:155-160.

11. Luo Y, Do J, Liu C: An amperometric uric acid biosensor based on modified Ir-C electrodes. Biosens Bioelectron 2006, 22:482-488.

12. Tsai W-Chi, Wen ST: Determination of uric acid in serum by a mediated amperometric biosensor. Anal Let 2006, 39:891-901.

13. Behera S, Raj CR: Mercaptoethylpyrazine promoted electrochemistry of redox protein and amperometric biosensing of uric acid. Biosens Bioelectron 2007, 23:556-561.

14. Arora K, Sumana G, Saxena V, Gupta R, Gupta S, Yakhmi J, Pandey M, Chand S, Malhotra B: Improved performance of polyaniline-uricase biosensor. Anal Chim Acta 2007, 594:17-23.

15. Wang $X$, Hagiwara T, Uchiyama S: Immobilization of uricase within polystyrene using polymaleimidostyrene as a stabilizer and its application to uric acid sensor. Anal Chim Acta 2007, 587:41-46.

16. Chauhan N, Pundir CS: An amperometric uric acid biosensor based on multiwalled carbon nanotube-gold nanoparticle composite. Anal Biochem 2011, 413:97-103. 
17. Bhambi M, Sumana G, Malhotra BD, Pundir CS: An amperomertic uric acid biosensor based on immobilization of uricase onto polyanilinemultiwalled carbon nanotube composite film. Artif Cells Blood Substit Immobil Biotechnol 2010, 38:178-185.

18. Tao H, Wang $X$, Wang $X$, Hu Y, Ma Y, Lu Y, Hu Z: Construction of uric acid biosensor based on biomimetic titanate nanotubes. J Nanosci Nanotechnol 2010, 10:860-864.

19. Lopes TS, Klootwijk J, Veenstra AE, van der Aar PC, van Heerikhuizen $H$, Raue HA, Planta RJ: High-copy-number integration into the ribosomal DNA of Saccharomyces cerevisiae: A new vector for high-level expression. Gene 1989, 79:199-206.

20. Parekh RN, Shaw MR, Wittrup KD: An integrating vector for tunable, high copy, stable integration into the dispersed Ty- $\delta$ Sites of Saccharomyces cerevisiae. Biotechnol Prog 1996, 12:16-21.

21. Sohn J, Choi E, Kang H, Rhee J, Agaphonov M, Ter-Avanesyan M, Rhee S: A dominant selection system designed for copy-number-controlled gene integration in Hansenula polymorpha DL-1. Appl Microbiol Biotechnol 1999, 51:800-807.

22. Gonchar MV, Maidan MM, Moroz OM, Woodward JR, Sibirny AA: Microbial $\mathrm{O}_{2}$ - and $\mathrm{H}_{2} \mathrm{O}_{2}$-electrode sensors for alcohol assays based on the use of permeabilized mutant yeast cells as the sensitive bioelements. Biosens Bioelectron 1998, 13:945-952.

23. Ishchuk OP, Voronovsky AY, Abbas CA, Sibirny AA: Construction of Hansenula polymorpha strains with improved thermotolerance. Biotechnol Bioeng 2009, 104:911-919.

24. Itaya K, Yamamoto T, Fukumoto J: Studies on yeast uricase. Part I. Purification and some enzymatic properties of yeast uricase. Agric Biol Chem 1967, 31:1256-1264.

25. Li J, Chen Z, Hou L, Fan H, Weng S, Xu C, Ren J, Li B, Chen W: High-level expression, purification, and characterization of non-tagged Aspergillus flavus urate oxidase in Escherichia coli. Protein Expr Purif 2006, 49:55-59.

26. Leplatois P, Le Douarin B, Loison G: High-level production of a peroxisomal enzyme: Aspergillus flavus uricase accumulates intracellularly and is active in Saccharomyces cerevisiae. Gene 1992, 122:139-145.

27. Gonchar M, Maidan M, Korpan Y, Sibirny V, Kotylak Z, Sibirny A: Metabolically engineered methylotrophic yeast cells and enzymes as sensor biorecognition elements. FEMS Yeast Research 2002, 2:307-314.

28. Knud A, Leo MJ: Process for the production of uricase. US Patent 3669843:1972

29. Markas A, Gilmartin T, Hart JP: Novel reagentless, amperometric biosensor for uric acid based on a chemically modified screen-printed carbon electrode coated with cellulose acetate and uricase. Analyst 1994, 119:833-840

30. Tatsuma T, Watanabe T: Oxidase:peroxidase bilayer-modified electrodes as sensors for lactate, pyruvate, cholesterol and uric acid. Anal Chim Acta 1991, 242:85-89.

31. Miland E, Ordieres AJM, Blanco PT, Smyth MR, Fagain CO: Poly(oaminophenol)-modified bienzyme carbon paste electrode for the detection of uric acid. Talanta 1996, 43:785-796.

32. Lahtchev KL, Semenova VD, Tolstorukov II, van der Klei I, Veenhuis M: Isolation and properties of genetically defined strains of the methylotrophic yeast Hansenula polymorpha. Arch Microbiol 2002, 177:150-158.

33. Sambrook J, Fritsch EF, Maniatis T: Molecular Cloning: A Laboratory Manual Cold Spring Harbor, New York; 1989.

34. Faber KN, Haima P, Gietl C, Harder W, Ab G, Veenhuis M: The methylotrophic yeast Hansenula polymorpha contains an inducible import pathway for peroxisomal matrix proteins with an $\mathrm{N}$-terminal targeting signal (PTS2 proteins). Proc Natl Acad Sci USA 1994, 91:12985-12989.

35. Veenhuis M, Hoogkamer-Te Niet MC, Middelhoven WJ: Biogenesis and metabolic significance of microbodies in urate-utilizing yeasts. Antonie Van Leeuwenhoek 1985, 51:33-43.

doi:10.1186/1472-6750-11-58

Cite this article as: Dmytruk et al: Construction of uricaseoverproducing strains of Hansenula polymorpha and its application as biological recognition element in microbial urate biosensor. BMC Biotechnology 2011 11:58.

\section{Submit your next manuscript to BioMed Central and take full advantage of:}

- Convenient online submission

- Thorough peer review

- No space constraints or color figure charges

- Immediate publication on acceptance

- Inclusion in PubMed, CAS, Scopus and Google Scholar

- Research which is freely available for redistribution

Submit your manuscript at www.biomedcentral.com/submit
C Biomed Central 